\title{
SISTEM ANALISIS FINANSIAL USAHA BUDIDAYA IKAN LELE DENGAN METODE FUZZY TSUKAMOTO
}

\author{
Ricky Mahendra Putra', Misbah, Umi Chotijah \\ 1) Teknik Informatika Universitas Muhammadiyah Gresik \\ Fakultas Teknik,Universitas Muhammadiyah Gresik \\ Jl. Sumatra 101 Gresik Kota Baru (GKB), Randuagung, 61121 \\ Telp.(031) 3951414 , Faks. (0561) 740186 \\ E-mail: ricky.mahendra.putra@gmail.com ${ }^{1)}$
}

\begin{abstract}
ABSTRAK
Pada kelompok budidaya ikan dimana pembudidaya ikan lele akan memilih kebutuhan perikanan yang sesuai kebutuhannya. Permasalahanya akhir-akhir ini pembudidaya ikan lele sering mengalami kerugian tiap panennya. Agar mendapatkan keuntungan, pembudidaya disarankankan memilih bahan baku seperti bibit, pakan, obat, populasi, \& luas kolam yang sesuai dengan kebutuhan pembudidaya. Penelitian ini menerapkan data mining dengan menggunakan metode Fuzzy Tsukamoto untuk menentukan untung dan rugi budidaya ikan lele. Atribut yang digunakan pada penelitian ini terdiri dari 6 variabel, yaitu musim, populasi, bibit, obat, pakan, dan luas kolam. .Pengujian sistem dilakukan sebanyak tiga kali pengujian. Berdasarkan pengujian yang telah dilakukan diperoleh : hasil prediksi musim hujan, bibit sangkuriang, pakan LP, obat boster, populasi 4000, luas kolam 16 M2 yang dapat menguntungkan pembudidaya. Dari semua hasil penelitian akurasi tertinggi terdapat pada pengujian kedua yaitu dengan nilai prediksi $68,56 \%$.
\end{abstract}

Kata kunci: Data Mining, Fuzzy Tsukamoto, Budidaya Ikan Lele.

\section{PENDAHULUAN}

Budidaya perikanan adalah usaha pemeliharaan dan pengembang biakan ikan atau organisme air lainnya. Budidaya perikanan disebut juga sebagai budidaya perairan atau akuakultur mengingat organisme air yang dibudidayakan bukan hanya dari jenis ikan saja tetapi juga organisme air lain seperti kerang, udang maupun tumbuhan air (Wheaton, 1977). Ikan Lele merupakan budidaya yang efisien dalam menghasilkan daging, namun disisi lain biaya dari faktor-faktor produksi usaha budidaya lele ini relatif tinggi yakni hampir $80 \%$ untuk biaya produksinya \& biaya pakan dari total penerimaan budidaya sehingga penggunaan faktorfaktor produksi harus seefisien mungkin. Disamping biaya yang harus dikeluarkan tidak sedikit, kapasitas pemeliharaan, biaya pakan yang cukup mahal, serta ditambah lagi harga lele yang dirasa rendah dibanding dengan biaya produksi yg mahal merupakan kendala dalam memperoleh keuntungan yang maksimal.

Pada kasus ini pembudidaya ikan lele di salah satu Desa di Kabupaten Lamongan dimana pembudidaya ikan lele akan memilih kebutuhan perikanan yang sesuai keinginanya. Permasalahanya akhir-akhir ini pembudidaya ikan lele sering mengalami kerugian setiap kali panen dikarenakan kesalahan dalam pemilihan bibit, pakan \& obat. Dengan adanya data tahun 2015 panen ternyata yang menjadi kendala adalah pemilihan bahan baku yang tidak sesuai seperti bibit, pakan, dan obat yang tidak cocok dengan PH air yang ada pada kolam, jika dibandingkan dengan penelitian sebelumnya yang dilakukan oleh Marwatin Fika P.W mahasiswa Fakultas Perikanan Universitas Jember di Desa Mojomulyo Kecamatan Puger Kabupaten Jember yang dapat meraih keuntungan dengan nilai $\mathrm{Net}$ Benefit Cast Ratio sebesar 1,74 yang artinya pengeluaran biaya sebesar Rp. 1.000.000,00 sehingga masih ada keuntungan sebesar Rp. $80.000,00$.

Berdasarkan pemaparan diatas maka dapat dilihat bahwa untuk memilih bahan baku yang sesuai untuk Budidaya ikan lele membutuhkan suatu sistem untuk mendapatkan informasi tentang untung dan ruginya suatu budidaya ikan lele. Penggunaan 
teknik data mining prediksi ada bermacam-macam metode dan setiap metode memiliki kelebihan dan kekurangannya masing-masing. Untuk kelebihan metode klasifikasi Fuzzy tersendiri yaitu mudah dipahami, hanya memerlukan pengkodean yang sederhana, lebih cepat dalam menghitung. Dan sistem ini sangat cocok untuk memprediksi untung dan ruginya budidaya ikan lele diambil 6 atribut yaitu musim, luas kolam, populasi, bibit (dumbo \& sangkuriang), obat (raja lele, boster, SOC), dan pakan (MegaFeed, LP, \& Cargil).

Penelitian dilakukan dengan judul "sistem analisis finansial usaha budidaya ikan lele dengan metode Fuzzy Tsukamoto" yang akan membantu pembudidaya untuk menjaga performa yang baik dan stabil sehingga dapat mengimbangi target performa dan mendapatkan keuntungan yang maksimal.

\subsection{Rumusan Masalah}

Adapun rumusan masalah adalah bagaimana cara untuk menganalisis finansial dari pemilihan jenis bibit, pakan, obat, dengan musim, populasi \& luas kolam yang sesuai dengan kebutuhan.

\subsection{Tujuan Penelitian}

Tujuan penelitian adalah membuat sistem presiksi untuk mempermudah pembudidaya dalam memilih jenis bibit, pakan, obat dengan musim, populasi \& luas kolam yang sesuai dengan kebutuhan.

\section{LANDASAN TEORI}

\subsection{Definisi Sistem}

Sistem secara fisik adalah kumpulan dari elemen-elemen yang beroperasi bersama-sama untuk menyelesaikan suatu sasaran (Gordon, 1991).

Menurut (Jagianto, 2005) Sistem adalah kumpulan dari elemen-elemen yang berinteraksi untuk mencapai suatu tujuan tertentu.

\subsection{Klasifikasi}

Klasifikasi adalah proses untuk menemukan model atau fungsi yang menjelaskan atau membedakan konsep atau kelas data, dengan tujuan untuk dapat memperkirakan kelas dari suatu objek yang labelnya tidak diketahui. Dalam mencapai tujuan tersebut, proses klasifikasi membentuk suatu model yang mampu membedakan data kedalam kelas-kelas yang berbeda berdasarkan aturan atau fungsi tertentu. Model itu sendiri bisa berupa aturan "Jika-maka", berupa pohon keputusan, atau formula matematis (Bustami, 2011)

\subsection{Fungsi Keanggotaan Fuzzy Tsukamoto}

Fungsi

Keanggotaan (membership function) adalah suatu kurva yang menunjukkan pemetaan titik-titik input data ke dalam nilai keanggotaannya (sering juga disebut dengan derajat keanggotaan) yang memiliki interval antara 0 sampai 1 . Ada beberapa fungsi yang bisa digunakan (Kusumadewi, 2003) :

1. Representasi Linier

Pada representasi linear, pemetaan input ke derajat keanggotannya digambarkan sebagai suatu garis lurus. Ada 2 keadaan himpunan fuzzy linear : Pertama, kenaikan himpunan dimulai pada nilai domain yang memiliki derajat keanggotaan nol [0] bergerak ke kanan menuju ke nilai domain yang memiliki derajat keanggotaan lebih tinggi. Sedangkan kedua, merupakan kebalikan yang pertama. Garis lurus dimulai dari nilai domain dengan derajat keanggotaan tertinggi pada sisi kiri, kemudian bergerak menurun ke nilai domain yang memiliki derajat keanggotaan lebih rendah. Berikut merupakan gambar representasi kurva naik dan representasi kurva turun.

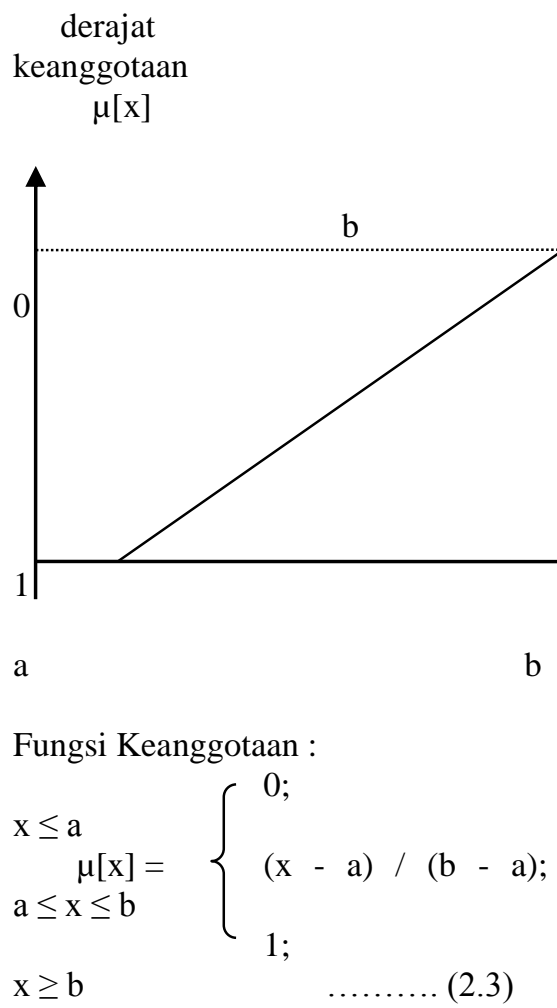


INDEXIA: Informatic and Computational Intelegent Journal

Ricky Mahendra Putra, Umi Chotijah

Sistem Analisis Finansial Usaha Budidaya Ikan Lele Dengan Metode Fuzzy Tsukamoto

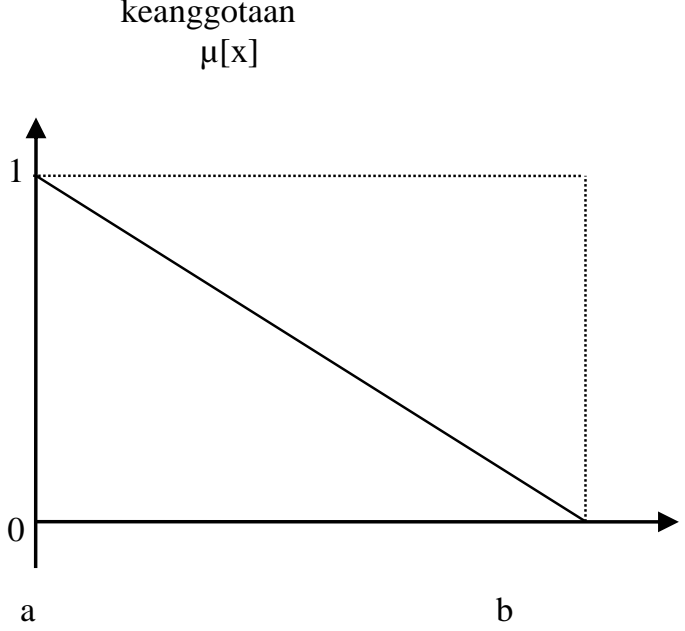

b

Fungsi Keanggotaan :

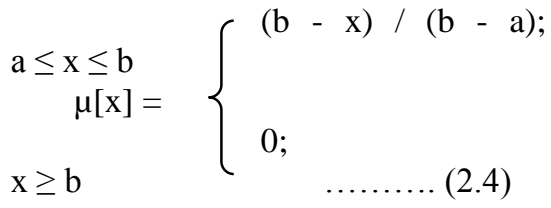

\subsection{Penelitian Sebelumnya}

Penelitian sebelumnya dilakukan oleh Mustabsyiroh, Mukhamad Nurkamid, Anastasya Latubessy, mahasiswa Program Studi Teknik Informatika, Fakultas Teknik, Universitas Muria Kudus, tahun 2014 dengan judul "Peramalan Tingkat Produktivitas Daerah Potensial Pangan di Kudus". Penelitian ini mengunakan metode berbasis FIS (Fuzzy Inference Sistem) Tsukamoto untuk melakukan peramalan tingkat produktivitas usaha pangan. Dengan data historial mulai 2011 sampai 2013, dapat dijadikan patokan dan mempelajari pola-pola kerja disetiap tahunnya. Penelitian ini bertujuan untuk melakukan meramal tingkat produktivitas dan klasifikasi dan identifikasi subsektor jenis tumbuhan yang menjadi komoditas produksi utama disetiap Kecamatan Kabupaten Kudus. Identifikasi dan klasifikasi subsektor pertanian pada usaha tanaman pangan diperlukan untuk memberikan gambaran jenis tanaman mana yang aktifitasnya menjadi basis perekonomian yang sangat potensial, potensial dan kurang potensial.

Selanjutnya penilitian sebelumnya juga dilakukan oleh I Putu Agus Aditya Pramana dan Wiwik Anggraeni, S.Si, M.Kom,Sistem Informasi, Fakultas Teknologi Informasi (FTIf), Institut Teknologi Sepuluh Nopember (ITS), tahun 2016dengan judul "Peramalan Jumlah Kasus Demam Berdarah di Kabupaten Malang Menggunakan Metode Fuzzy Inference System ". Penelitian ini akan membahas model sistem peramalan menggunakan Fuzzy Inference System metode Tsukamoto untuk meramalkan jumlah kasus Demam Berdarah di kabupaten Malang. Peramalan jumlah kasus Demam Berdarah di Kabupaten Malang ini menggunakan variabel kepadatan penduduk. Jumlah kasus Demam Berdarah dari kecamatan dikelompokkan menjadi tiga berdasarkan letak geografisnya, yaitu Dataran Rendah, Dataran Sedang, dan Dataran Tinggi. Pengelompokkan ini bertujuan untuk melihat pengaruh letak georafis kecamatan terhadap dinamika jumlah kasus demam Berdarah.

\section{ANALISIS DAN PERANCANGAN SISTEM 3.1 Analisis Sistem}

Budidaya ikan Lele adalah suatu bidang bisnis yang memiliki resiko cukup tinggi dengan tingkat keuntungan atau kerugian. Dalam semua bidang usaha, jika berpotensi menghasilkan pendapatan yang besar umumnya memiliki resiko yang besar juga. Hanya orang-orang yang mampu bertahan dan mampu menyelesaikan kendala dan juga masalah dalam bisnis mereka tersebut yang akan berhasil mengembangkan bisnis mereka. Salah satu faktor yang mempengaruhi keuntungan dan kerugian pada bisnis Budidaya ikan lele yaitu bibit, pakan, obat dalam Budidaya ikan Lele. Pembuatan system Prediksi untung rugi Budidaya Lele ini diimplementasikan dengan menerapkan teknik data mining menggunakan metode Fuzzy Tsukamoto.

Proses prediksi dilakukan dengan menerapkan teknik data mining klasifikasi menggunakan metode Fuzzy Tsukamoto. Teknik tersebut membutuhkan data pembelajaran, yaitu data Budidaya Kelompok Budidaya Ikan Lele "Makmur Sentosa" yang nantinya akan digunakan bagi para pembudidaya yang akan memilih kebutuhan budidaya lele. Proses prediksi yang dibangun akan menghasilkan nilai keluaran berupa kategori untung atau rugi. Untuk proses menghitung metode Tsukamoto ada beberapa langkah-langkah, yang pertama Menentukan nilai ke anggotaannya setiap variabel, menentukan nilai a-predikat, menentukan z1, dan yang terakhor adalah menentukan Defuzzyfikasi yang nantinya akan mengetahui hasil akhir dari data uji berupa untung atau Rugi.

\subsection{Hasil Analisis}

Hasil analisis yang dapat dilakukan dari sistem prediksi untung rugi pada hasil budidaya ikan Lele yang dibangun nantinya dapat mengetahui untung dan rugi budidaya lele yang diperoleh dari pengolahan data data budidaya, meliputi : Musim, Populasi, Luas kolam, bibit, pakan, dan obat yang nantinya data tersebut akan diolah dengan menggunakan metode Tsukamoto, hasil yang diperoleh dari perhitungan metode Tsukamoto adalah berupa informasi yang dapat membantu 
INDEXIA: Informatic and Computational Intelegent Journal

Ricky Mahendra Putra, Umi Chotijah

Sistem Analisis Finansial Usaha Budidaya Ikan Lele Dengan Metode Fuzzy Tsukamoto

Pembudidaya dalam mengetahui untung dan rugi dalam budidaya ikan lele.

Kebutuhan fungsional untuk sistem prediksi untung rugi pada hasil budidaya ikan Lele adalah :

1. Sistem dapat melakukan input data informasi dari pembudidaya.

2. Menentukan fungsi keanggotaannya setiap variabel, menentukan nilai nilai keanggotaan tiap variabel, dan yang terakhor adalah menentukan Defuzzyfikasi.

3. Sistem dapat melakukan prediksi keterangan untung rugi data baru yang akan di inputkan pembudidaya berdasarkan data latih yang telah tersimpan di database menggunakan Tsukamoto.

4. Atribut yang digunakan meliputi musim, populasi, luas kolam, bibit, obat, dan pakan.

5. Sistem dapat memberikan hasil laporan dari prediksi berupa data untung atau rugi.

Sistem yang dibangun merupakan aplikasi atau tool prediksi pembudidaya ikan lele dengan menggunakan metode Tsukamoto. Sistem ini akan menghasilkan input berupa perkiraan kategori keterangan Budidaya ikan lele yang tergolong kedalam kategori untung dan rugi.

Terdapat beberapa atribut yang dibutuhkan untuk memprediksi budidaya ikan lele ini diantaranya adalah adalah musim, populasi, luas kolam,bibit, obat, dan pakan.

Hasil dari sistem ini nantinya adalah menampilkan daftar budidaya ikan lele yang diprediksi mempunyai keterangan untung dan rugi.

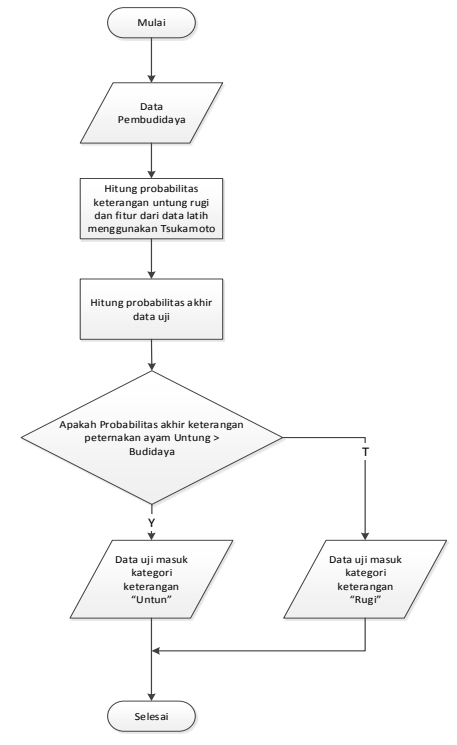

Gambar 1 Flow Chart Sistem Prediksi

\subsection{Perancangan Sistem}

\subsubsection{Context Diagram Sistem}

Context diagram adalah diagram yang terdiri dari suatu proses dan menggambarkan ruang lingkup suatu sistem. Berikut ini gambar context diagram dari aplikasi peternakan ayam broiler. Gambar cortext diagram dapat dilihat pada gambar 2 :

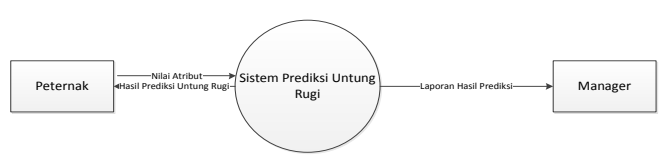

Gambar 2 Context Diagram Sistem Prediksi

Untung Rugi Budidaya Ikan Lele

Pada context diagram gambar 3.8 ini merupakan gambaran sistem secara garis besar, dimana terdapat tiga entitas luar yang berhubungan dengan sistem, yaitu :

1. Pembudidaya merupakan pihak yang memasukkan kuesioner (atribut) dan menerima hasil prediksi berupa jumlah keuntungan / kerugian.

2. Ketua Kelompok merupakan pihak yang dapat melihat hasil laporan prediksi semua Pembudidaya.

\subsubsection{Diagram Berjenjang}

Diagram berjenjang merupakan diagram yang menjelaskan secara keseluruhan blok proses yang ada pada sistem. Gambar diagram berjenjang dapat dilihat pada gambar 3 :

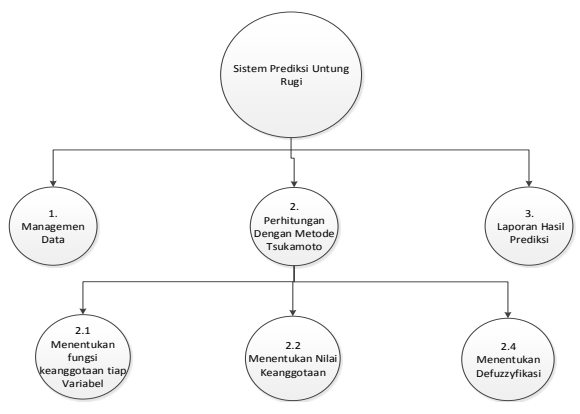

Gambar 3 Diagram Berjenjang Sistem Prediksi Untung Rugi Budidaya Ikan lele

Pada gambar 3 di atas dapat dijelaskan sebagai berikut :

a. Top level : Sistem prediksi untung rugi berdasarkan latar belakang pemilihan kebutuhan ketika sebelum melakukan budidaya ikan lele.

b. Level 0 : 1. Managemen Data 2. Perhitungan Tsukamoto

3. Laporan Hasil Prediksi

- Level 1 : 2.1 Menentukan fungsi keanggotaan tiap variabel 
INDEXIA: Informatic and Computational Intelegent Journal

Ricky Mahendra Putra, Umi Chotijah

Sistem Analisis Finansial Usaha Budidaya Ikan Lele Dengan Metode Fuzzy Tsukamoto

\subsection{Menghitung nilai \\ Keanggotaan tiap variabel \\ 2.3 Menghitung Defuzzyfikasi}

\subsubsection{Data Flow Diagram (DFD) a. DFD Level 0}

DFD level 0 merupakan gambaran bagaimana sistem berinteraksi dengan external entity. Gambar DFD level 0 dapat dilihat pada gambar 4 :

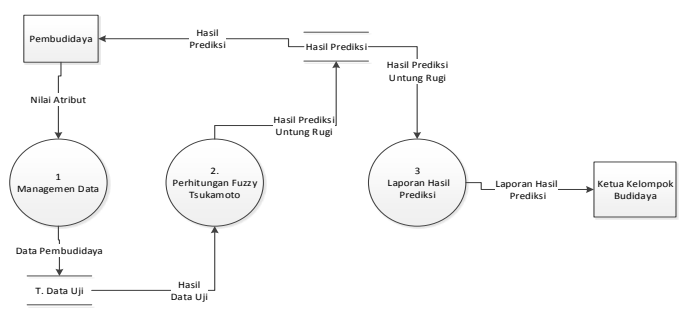

\section{Gambar 4 DFD Level 0}

Pada gambar 3.10 diatas dapat dijelaskan sebagai berikut :

a. Proses 1 adalah proses managemen data yang di inputkan oleh Pembudidaya.

b. Proses 2 adalah perhitungan Tsukamoto yaitu proses perhitungan dengan menggunakan metode Tsukamoto dan Pembudidaya mendapatkan informasi hasil prediksi Pembudidaya Ikan lele.

c. Proses 3 adalah pembuatan laporan hasil prediksi yaitu pembuatan laporan dari daftar hasil prediksi yang telah dilakukan Pembudidaya dalam pemilihan kebutuhan budidaya.

\section{b. DFD Level 1 Proses 2}

DFD level 1 proses 2 merupakan gambaran bagaimana sistem berinteraksi dengan external entity. Gambar DFD level 1 proses 2 dapat dilihat pada gambar 5 :

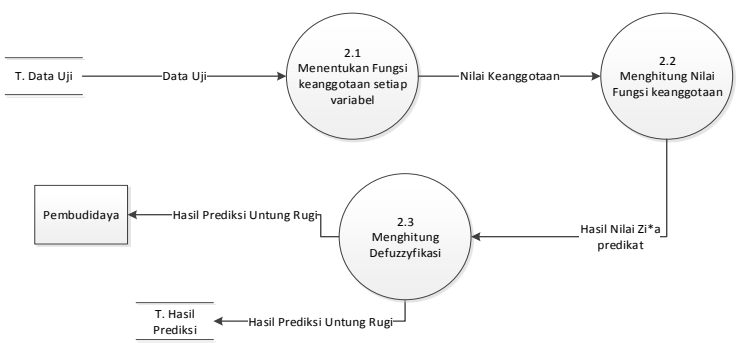

Gambar 5 DFD Level 1 proses 2
Pada gambar 5 diatas dapat dijelaskan sebagai berikut :

a. Proses 2.1 adalah proses menetukan fungsi keanggotaan setiap variabel yang digunakan dalam memprediksi untung rugi. Fitur yang digunakan adalah musim, populasi, luas kolam, bibit, pakan, dan obat.

b. Proses 2.2 adalah proses menghitung nilai fungsi keanggotaan dari setiap variabel dan akan diambil nilai terendah dari semua variabel disetiap rule.

c. Proses 2.3 adalah proses Defuzzyfikasi dengan menghitung nilai a-predikat \& $\mathrm{Z}$ disemua rule dan akan bisa mengetahui bahwa prediksi menghasilkan untung / rugi.

\section{IMPLEMENTASI DAN PENGUJIAN 4.1 Implementasi}

Implementasi sistem adalah bentuk dari hasil perancangan sistem yang dilakukan sebelumnya. Pada bab ini akan dijelaskan mengenai implementasi dan pengujian dari aplikasi implementasi metode Fuzzy Tsukamoto sebagai penentu untung rugi budidaya ikan lele yang bertujuan untuk mengetahui untung dan rugi sebuah budidaya ikan lele dengan menggunakan metode Fuzzy Tsukamoto.

\subsection{Implementasi Desain Interface}

Menu login seperti pada gambar 6 merupakan halaman pertama kali yang muncul saat user menjalankan aplikasi, Pada halaman ini terdapat form login yang harus diisi yaitu username dan password.

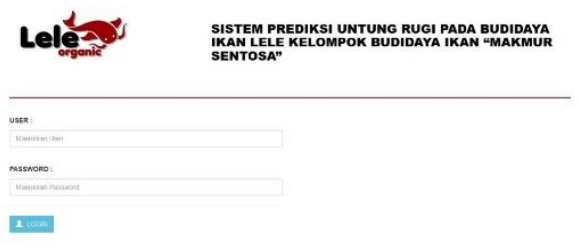

Gambar 6. Login Sistem 
INDEXIA: Informatic and Computational Intelegent Journal

Ricky Mahendra Putra, Umi Chotijah

Sistem Analisis Finansial Usaha Budidaya Ikan Lele Dengan Metode Fuzzy Tsukamoto

Untuk dapat mengakses menu-menu lain sesuai dengan hak akses user, maka user harus login terlebih dahulu. Tampilan untuk masing-masing user setelah proses login dapat dilihat pada gambar 7 , dan 8

Sistem Prediksi Untung Rugi Budidaya Ikan Lele Kelompok Budidaya Ikan 'Makmur Sentosa'

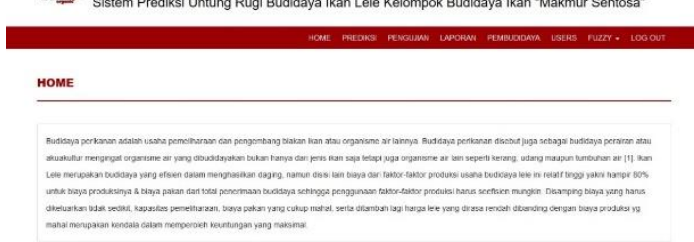

Gambar 7 Tampilan Sistem untuk User Administrator

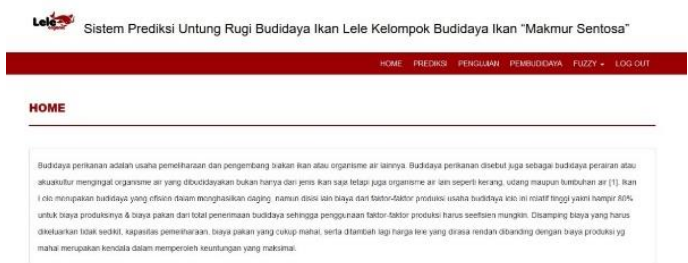

Gambar 8 Tampilan Sistem untuk User Peternak

\subsubsection{Menu Prediksi}

Menu pada gambar 9 merupakan halaman yang digunakan untuk para pembudidaya untuk melakukan input data prediksi

\section{PREDIKSI METODE FUZZY TSUKAMOTO}

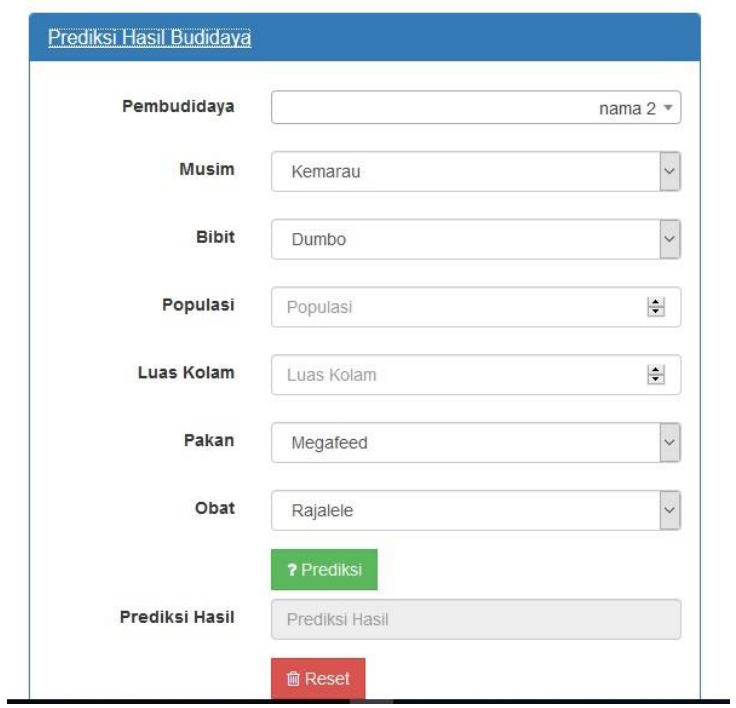

Gambar 9 Tampilan Sistem untuk Prediksi
Setelah

pembudidaya memasukkan beberapa atribut kedalam menu prediksi, maka hasil prediksi akan nampil seperti apda gambar 10 dibawah ini.

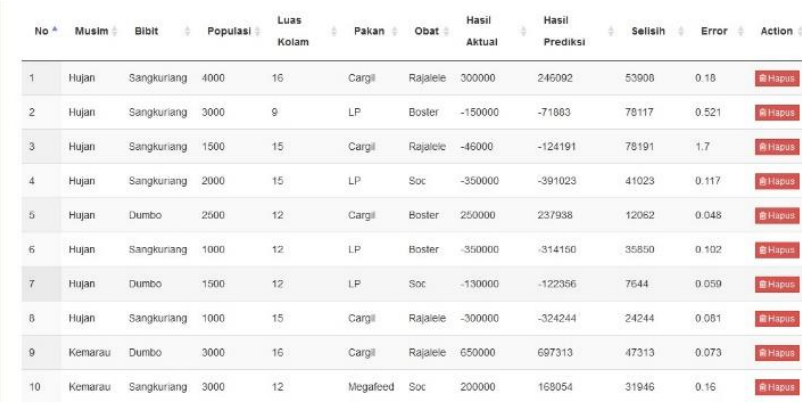

Gambar 10 Tampilan hasil prediksi

\subsubsection{Menu Laporan}

Menu laporan hasil prediksi seperti pada gambar 11 merupakan menu yang digunakan Admin untuk melihat hasil laporan yang telah dilakukan Pembudidaya. Laporan hasil prediksi akan ditampilkan dalam bentuk tabel.

Lel- Sistem Prediksi Untung Rugi Budidaya Ikan Lele Kelompok Budidaya Ikan "Makmur Sentosa" HOME PREOKSI PENGUANAN

LAPORAN

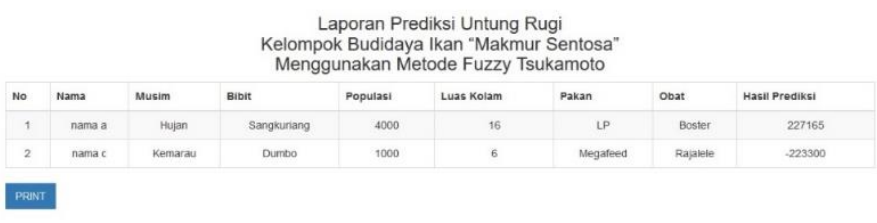

Gambar 11 Tampilan Menu Hasil Prediksi

\subsubsection{Menu Data Pembudidaya}

Pada gambar 12 merupakan menu yang ada di admin yang digunakan untuk mengubah identitas para pembudidaya ikan lele.

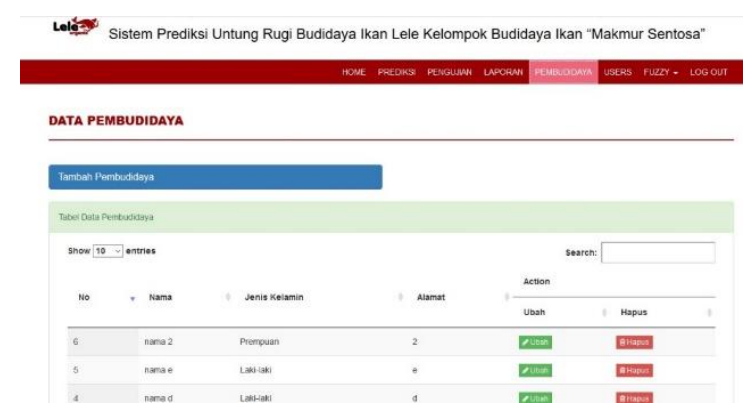


INDEXIA: Informatic and Computational Intelegent Journal

Ricky Mahendra Putra, Umi Chotijah

Sistem Analisis Finansial Usaha Budidaya Ikan Lele Dengan Metode Fuzzy Tsukamoto

Gambar 12 Tampilan Menu Pembudidaya

\subsubsection{Menu User}

Gambar 13 merupakan halaman menu menambah data pembudidaya maupun admin.

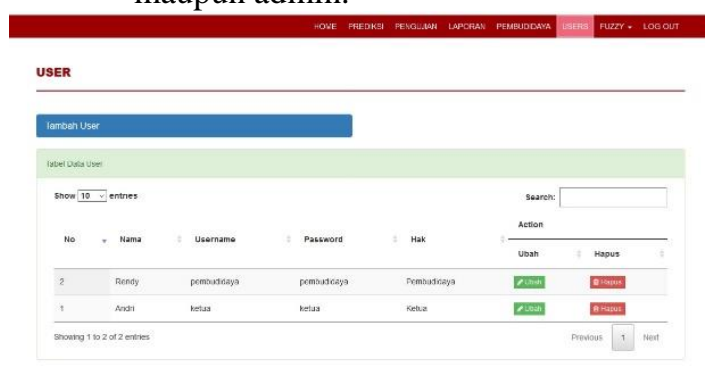

Gambar 13 Tampilan Menu User

\section{PENUTUP}

5.1 Kesimpulan

Skripsi ini menghasilkan beberapa kesimpulan sebagai berikut :

1. Sistem dapat memprediksi finansial pada usaha Budidaya Ikan Lele.

2. Data uji yang digunakan dalam proses klasifikasi mempengaruhi hasil pengujian. Semakin banyak data uji yang digunakan dan semakin bervariasi data uji hasil akurasi yang diperoleh akan semakin baik.

3. Penentuan data uji yang digunakan untuk klasifikasi dilakukan secara trial and error, untuk mendapatkan akurasi terbaik. Akurasi yang didapatkan pada pengujian sistem ini adalah 68,56\%.

\subsection{Saran}

Saran penulis terhadap skripsi ini adalah sebagai berikut :

1. Sistem sebaiknya dikembangkan dengan menambah jumlah data uji yang digunakan agar memperoleh nilai akurasi yang lebih baik.

2. Penentuan data uji pada pengujian sistem masih dilakukan secara trial and error, sehingga sebelum melakukan proses prediksi dilakukan preprocessing pada data latih untuk menghilangkan noise yang terjadi dan menghasilkan data yang berkualitas.

3. Tampilan halaman sebaiknya lebih dikembangkan dengan semenarik mungkin dengan tampilan-tampilan yang lebih efisien.
Anonim, 2013. Jenis-jenis ikan lele budidaya.

Anonim, 2016. 5 Jenis Ikan Lele Unggul di Indonesia. http://www.indoaqua.net/2016/01/5-jenisikan-lele-unggul-di-indonesia.html

Dwi Rosalina. 2013. Analisis Kelayakan Usaha Budidaya Ikan Lele di Kolam Terpal di Desa Namang Kabupaten Bangka Tengah

Jogiyanto, H.M. 2005. Analisis dan Desain: Sistem Informasi Pendekatan Terstruktur Teori dan Praktek Aplikasi Bisnis. Yogyakarta: ANDI.

Kadir A, Triwahyuni TCH. 2003. Pengenalan Teknologi Informasi. Yogyakarta: Andi

Khairani Diana. 2013. Perencanaan dan Pengendalian Produksi. Yogyakarta : Graha Ilmu.

KKP, 2012. Petunjuk Teknis Budidaya Lele di Kolam Terpal. Dit. Produksi. http://kurniasandy.weebly.com/uploads/4/9/ 6/5/49650347/juknis-lele-dumbo-clarias-spdi-kolam-terpal-2012.pdf

Kusumadewi Sri. 2003. Artificial Intelligence (Teknik dan Aplikasinya). Yogyakarta : Graha Ilmu.Negeri.

Marwatin Fika P.W, Anik Suwandari, dan Rudi Hartadi, Analisis Kelayakan Finansial Dan Kontribusi Pendapatan Terhadap Pendapatan Rumah Tangga Pembididaya Ikan Lele Dumbo

Suryani Dwi Rahmawati 2013. Sistem Peramalan harga jual rumah dengan menggunakan metode Tsukamoto Studi Kasus D'ahsana Property Randuagung Gresik. Universitas Muhammadiyah Gresik.

Standar Nasional Indonesia, 2000. Induk ikan lele dumbo (Clarias gariepinus $x$ C. fuscus) kelas induk pokok (Parent Stock).

Wheaton, F.W. (1977). Aquacultural Engineering

\section{DAFTAR PUSTAKA}

